Atmos. Chem. Phys. Discuss., 4, 3359-3380, 2004

www.atmos-chem-phys.org/acpd/4/3359/

4, 3359-3380, 2004

High ozone at rural sites in India

D. Chand and S. Lal

\title{
High ozone at rural sites in India
}

D. Chand ${ }^{1,2}$ and S. Lal ${ }^{1}$

${ }^{1}$ Physical Research Laboratory, Navrangpura, Ahmedabad, India

${ }^{2}$ Now at Max Planck Institute for Chemistry, Mainz, Germany

Received: 22 April 2004 - Accepted: 1 June 2004 - Published: 22 June 2004

Correspondence to: D. Chand (duli@mpch-mainz.mpg.de)

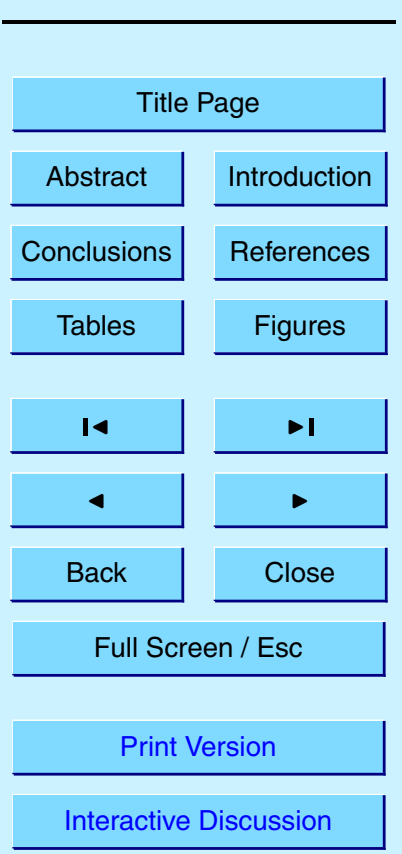

(C) EGU 2004 


\section{Abstract}

Past observations of $\mathrm{O}_{3}$ at urban, rural and lower free tropospheric sites in India have shown generally low values rarely exceeding $60 \mathrm{ppbv}$. We show that this can not be generated to all over India. Surface ozone $\left(\mathrm{O}_{3}\right)$ concentrations are obtained from mea5 surements in rural, urban and free tropospheric environments in January 2001 and 2002 as a part of Mobile Lab Experiments (MOLEX) conducted in western India. Elevated $\mathrm{O}_{3}$ from 70 to $110 \mathrm{ppbv}$ (nmole/mole) are recorded during afternoon hours at rural sites in downwind of major industrial region of Gujarat adjoining the Arabian Sea. Repeated observations during both the years indicate that this is a regular process in this region. The average background ozone is found to be $42 \pm 6 \mathrm{ppbv}$. The elevated ozone in the downwind site is about $60 \%$ higher than that in the major urban center and its surroundings and by a factor of 2 higher than the background levels of $\mathrm{O}_{3}$ in this region. In comparison to the downwind observations; the ozone observed at the continental stations in rural (Gadanki), urban (Ahmedabad) and free tropospheric (Mt.

$15 \mathrm{Abu}$ ) sites in India are low and rarely exceeded $60 \mathrm{ppbv}$ during the month of January. Forward trajectory analysis shows that the polluted plumes from this urban area can get transported more than $3000 \mathrm{~km}$ to the marine boundary layer over the Arabian Sea and the Indian Ocean within a week. Similar transport of pollutants from major urban sites like Delhi and other cities can enhance $\mathrm{O}_{3}$ in their downwind rural sites and can affect the human health as well as vegetation significantly.

\section{Introduction}

Ground level ozone, one of the gaseous air pollutants, is significantly exceeding the permissible concentrations in several regions (Proyou et al., 1991; Ballaman, 1993). Its background concentrations have been reported to increase during the last decades and it is expected that its concentration will continue to rise further during the coming years (Chameides et al., 1994; Jonson et al., 2001). The background ozone concentration
ACPD

4, 3359-3380, 2004

High ozone at rural sites in India

D. Chand and S. Lal

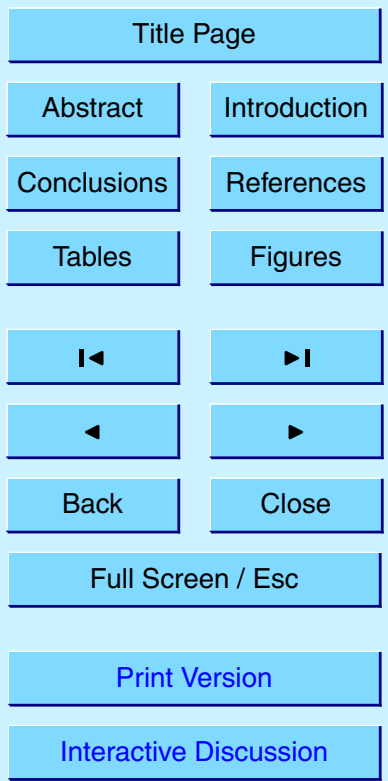

(C) EGU 2004 
at Ahmedabad, India is observed to have increased significantly from 1954-1955 to 1991-1993 (Naja and Lal, 1996).

High ozone concentrations have long been known to affect many physiological and biochemical characteristics (Reich and Amundson, 1985) as well as growth yield of 5 agricultural crops (Krupa et al., 1995; Chameides et al., 1999) and natural vegetation (Hogsett et al., 1997). Ozone is a reactive oxidant gas and its high dose has adverse effect on human health (Miller, 1995). Absorption of $\mathrm{O}_{3}$ occurs in all regions of the respiratory system causing many health problems (Chang et al., 1991). The tropospheric $\mathrm{O}_{3}$ is also important in determining the oxidizing capacity of the atmosphere, 10 both through its direct role, and through its role as a precursor of the hydroxyl radical $\mathrm{OH}$. Details of the chemistry of tropospheric ozone and its budget are described elsewhere (Kelly et al., 1984; Crutzen et al., 1999; Brasseur et al., 1999; Kley et al., 1999).

Recently, considerable attention has been given to the transport and transformation 15 of pollutants from south and south-east Asia to their surrounding marine environments (Lelieveld et al., 2001; Chand et al., 2003). The Indian Ocean Experiment (INDOEX) results have shown a pollution haze over the Arabian Sea and the Indian Ocean as a result of transport of pollutants from the Indian subcontinent (Ramanathan et al., 2001). Elevated ozone levels (60-70 ppbv) were observed in a remote marine environment over the Arabian Sea during INDOEX 1999. However, it was not discernable whether these elevated levels were transported from the free troposphere or were produced and/or transported from the continental source regions (Lal and Lawrence, 2001). Limited observations available from the continental stations in India at urban, rural and free tropospheric sites generally show low levels of ozone over the Indian 25 subcontinent (Varshney and Aggarawal, 1992; Khemani et al., 1995; Lal et al., 2000; Lal and Lawrence, 2001; Nair et al., 2002; Naja and Lal, 2002). Ozone observations in downwind of urban environment in India are not reported so far to our knowledge.

In this article, we present the first $\mathrm{O}_{3}$ observations at urban city, its downwind and surroundings in the Indian subcontinent. Section 2 describes the experimental meth-
ACPD

4, 3359-3380, 2004

High ozone at rural sites in India

D. Chand and S. Lal

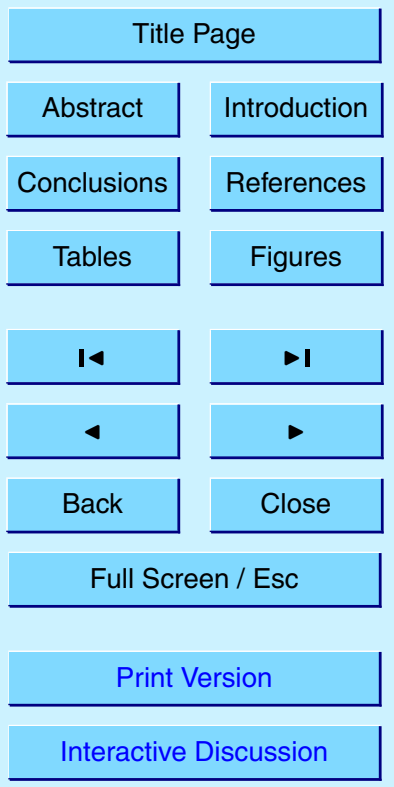

(C) EGU 2004 
ods briefly followed by the results, discussions and conclusions in Sects. 3, 4 and 5, respectively.

ACPD

4, 3359-3380, 2004

\section{Experimental methods}

\subsection{Monitoring sites}

5 The first mobile lab experiment (MOLEX) was conducted in downwind of Ahmedabad (capital urban city of Gujarat) during 22-27 January 2001. Two instrumented mobile vans were employed to increase the data set in the limited observational period. Each mobile van carried one ozone analyzer and the third ozone analyzer was kept at the Physical Research Laboratory (PRL) in Ahmedabad. In addition to the observations 10 in January 2001, the repeatability of the observations was made by making measurements from 30 December 2001 to 5 January 2002 at the same sites (Ahmedabad and Khambat).

Ozone observations were made at polluted site (Ahmedabad) and its surroundings in urban, rural and free tropospheric environments at Ahmedabad $\left(23^{\circ} \mathrm{N}, 72.6^{\circ} \mathrm{E}, 49 \mathrm{~m}\right)$, 15 Khambat $\left(22.2^{\circ} \mathrm{N}, 72.4^{\circ} \mathrm{E}, 15 \mathrm{~m}\right)$ and Mt. Abu $\left(24.6^{\circ} \mathrm{N}, 72.6^{\circ} \mathrm{E}, 1680 \mathrm{~m}\right)$, respectively. The heights of all the stations mentioned at the geographical locations are above mean sea level. Measurements made at rural site in south India Gadanki $\left(13.5^{\circ} \mathrm{N}, 79.2^{\circ} \mathrm{E}\right.$, $375 \mathrm{~m}$ ) are also used for an inter-comparison. Continuous measurements of ozone were made at a remote mountaintop called Guru Shikhar at Mt. Abu (hereafter, only Mt. Abu will be mentioned) in January of 2000 and 2001. This region comes under the southern end of Aravali range of mountains and is the highest in the entire western central Indian region. It is about $200 \mathrm{~km}$ north of Ahmedabad. In winter, the average wind pattern is such that Ahmedabad is in downwind of Mt. Abu. Details of this station and some results of ozone measurements are discussed elsewhere (Chand, 2002; 25 Naja et al., 2003).

Figure 1 shows the mobile tracks covered by mobile vans. We used roads having

\section{High ozone at rural} sites in India

D. Chand and S. Lal

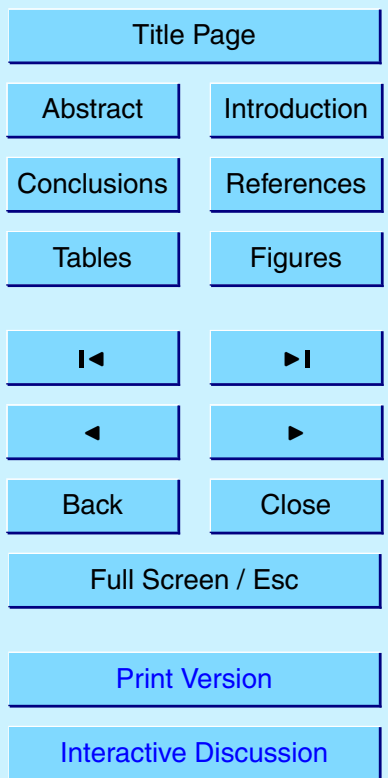

(C) EGU 2004 
very little traffic to avoid the sampling from vehicle exhausts. The circles in Fig. 1 are the main urban centers and the sizes of the circles are proportional to the population of these urban centers. The numbers along the track indicate the date of observations in mobile phase during daytime. All the night-time observations during the campaign were 5 made at stationary (pre-planed) sites without using the electrical generators. Khambat is a small town, about $80 \mathrm{~km}$ south of Ahmedabad as shown in Fig. 1. Ozone measurements were taken at Khambat for more than 20 h on 25-26 January 2001. We had to stop these measurements due to a severe earthquake on 26 January 2001 in this region. These observations at Khambat along with observations at urban center 10 at Ahmedabad were repeated for longer time in the same season during 30 December 2001 to 6 January 2002 to confirm the repeatability of results from the first campaign.

Background levels of ozone are obtained from the observations made at the remote free tropospheric site Mt. Abu. Ahmedabad (urban site) and its downwind measurements are used to assess the magnitude of ozone production in out flow of the urban plume. Mt. Abu and Khambat observations in upwind (free-troposphere) and downwind of Ahmedabad, respectively, are used for estimating the excess ozone in downwind outflow of urban plumes.

\subsection{Instrumentation and data reduction}

The ozone measurements were made using Dasibi (Model 1008, USA) and Environ-

mental S.A. (Model 41M, France) analyzers, based on the principle of UV absorption by ozone at $253.7 \mathrm{~nm}$. All the analyzers are calibrated and inter-compared before the campaign. Uncertainties of the measurements among all analyzers are within $\pm 3 \%$. The details of the calibrations of these analyzers are discussed elsewhere (Lal et al., 2000; Chand, 2002). Air inlets were taken from the front of the vans to avoid the contamination from exhaust of vans and power generators. The data from the national highways, Ahmedabad-Bagodra-Rajkot and Ahmedabad-Vadodara are not used in this study. The ambient air was sampled at the height of about $20 \mathrm{~m}$ from the ground into the ozone analyzer at PRL, Ahmedabad. Stainless steel and teflon tubes of $1 / 4$ and $1 / 2$

ACPD

4, 3359-3380, 2004

High ozone at rural sites in India

D. Chand and S. Lal

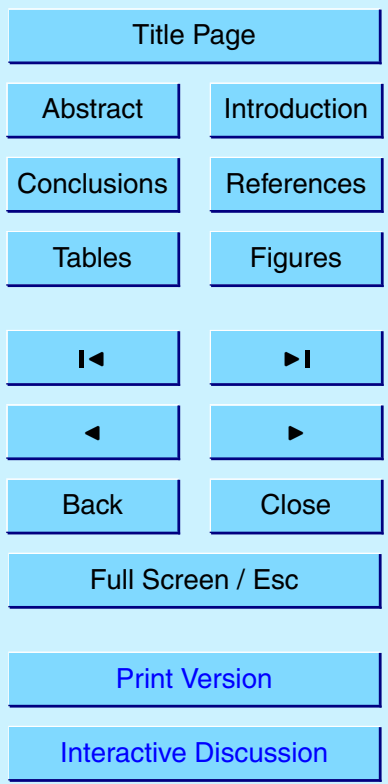

(C) EGU 2004 
inch diameters are used for the sampling lines. The lengths of sampling tubes were kept short within 6 meters for all the observations. Maximum loss of $\mathrm{O}_{3}$ in the sampling lines is less than $2 \%$ of its concentration and the data are corrected for these losses.

The time mentioned in this study is local Indian Standard Time (IST) which is $5.5 \mathrm{~h}$ 5 ahead of GMT. The sampling intervals at Ahmedabad and in mobile vans were taken as $1 \mathrm{~min}$ whereas the data were stored at every $5 \mathrm{~min}$ interval at Mt. Abu. Diurnal amplitude of $\mathrm{O}_{3}$ is calculated by taking difference in maximum average $\mathrm{O}_{3}$ levels in the afternoon hours and minimum $\mathrm{O}_{3}$ before sunrise. The increase rate of $\mathrm{O}_{3}\left(\mathrm{dO}_{3} / \mathrm{dt}\right)$ is calculated using least square fit to $\mathrm{O}_{3}$ concentrations at hourly interval between 07:00 to $12: 00 \mathrm{~h}$. The averaged values are shown with a dispersion of ( 1 sigma) $\sigma$.

\subsection{Meteorology}

The wind pattern in India changes dramatically from south-west to north-east during the pre-winter months. In western India, pre-winter months show weak winds whereas the winter is dominated by relatively stronger winds (Chand, 2002; Naja et al., 2003). 15 Such changes in wind patterns are observed each year (Asnani, 1993). The consistently stronger continental wind flow from north and north-eastern direction swaps the pollutants from the Indian region and transport them to the remote land and marine environments in this region. In winter, when the winds are northerly or north-easterly, the polluted air from Ahmedabad and Vadodara passes over Khambat on the way to the

20 Arabian Sea. Figure 2 displays the movement of air parcel shown by forward trajectory (FT) originated from Ahmedabad. The air has descending motion most of the times in the boundary layer. The data from National Center for Environmental Prediction (NCEP) are used for wind field analysis. Hybrid Single Particle Lagrangian Integrated Trajectory (HySPLIT-4) Model (version-4) is used for getting the FTs. Details of the 25 model description are given in Draxler and Hess (1998). Faint gray lines in Fig. 1 show the average NCEP wind fields during the MOLEX period. The NCEP winds are at coarse resolution and give rough estimate only. The average wind speed was in the

ACPD

4, 3359-3380, 2004

High ozone at rural sites in India

D. Chand and S. Lal

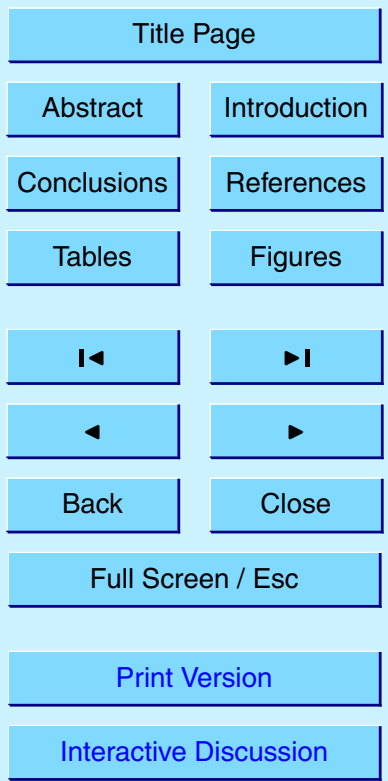

(C) EGU 2004 


\section{Results}

4, 3359-3380, 2004

\subsection{Ozone at urban and surrounding sites}

Figure 3a depicts the average diurnal variation of ozone at urban site (Ahmedabad) 5 and at different routes in its surroundings on mobile track during 22-26 January 2001 (see Fig. 1 for track). The average diurnal variations of ozone at Ahmedabad during 22-26 January 2001 show maximum $\mathrm{O}_{3}$ of about $52 \mathrm{ppbv}$ in the afternoon hours. High ozone levels persisted for more than $4 \mathrm{~h}$ from $12: 30 \mathrm{~h}$ to 17:00 h. Lowest levels of ozone $(12 \pm 3 \mathrm{ppbv})$ were observed before sunrise. Generally, the boundary layer is 10 most shallow and isolated with the free troposphere at this time with stronger inversion. Ozone losses by dry deposition and chemistry during the night hours result decrease in ozone concentration until the sun rises.

The observed amplitude of diurnal variation in ozone in daytime at Ahmedabad is about $40 \mathrm{ppbv}$. After sunrise, ozone increased at the rate of $6.7 \mathrm{ppbv} \mathrm{h}^{-1}$ and it takes about six hours to attain the peak levels. The ozone values observed in the downwind of urban center on 24, 25 and 26 January are 20-30 ppbv higher compared to the values at Ahmedabad (Fig. 3a). The ozone levels for these three consecutive days at Bagodra-Bhavanagar-Mahua, Mahua-Gadada and Khambat tracks show higher ozone levels of $78-86 \mathrm{ppbv}$. The net daytime increase of ozone in downwind is about $65 \mathrm{ppbv}$, which is about $60 \%$ higher than the ozone increase at urban site Ahmedabad. Ozone levels increased at a rate of $\sim 10 \mathrm{ppbv} \mathrm{h}^{-1}$ after sunrise. It takes $5-7 \mathrm{~h}$ to attain the maximum levels after sunrise at these sites. All the three consecutive days on mobile track showed high ozone concentrations than at Ahmedabad. There are some variations in the daytime and nighttime ozone levels possibly due to variations in the levels of pollutants at these sites.

The amplitudes of ozone diurnal variations on Rajkot-Babra, Gadada-Bagodra and

\section{High ozone at rural} sites in India

D. Chand and S. Lal

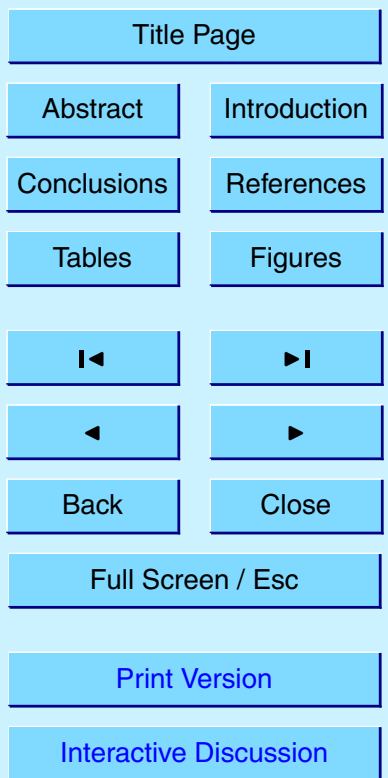

(C) EGU 2004 
Ahmedabad-Vishnagar tracks, which do not fall in the downwind of the pollution plume, are in the range of 50-60 ppbv (Fig. 3b). The observed average increase rate in ozone at these sites is about $4.2 \mathrm{ppbv} \mathrm{h}^{-1}$, which is lower than that observed at Ahmedabad.

Figure $3 c$ shows the average diurnal variation of ozone at Ahmedabad and its down5 wind side at Khambat during the second campaign from 30 December 2001 to 6 January 2002. The average peak ozone of about $55 \pm 6 \mathrm{ppbv}$ is observed in the afternoon hours at Ahmedabad. The observed increase rate in ozone is about $4.2 \mathrm{ppbv} \mathrm{h}^{-1}$ adding $27 \mathrm{ppbv}$ of ozone in daytime hours. There is some difference in average diurnal variation in ozone particularly the night time values being lower during 2002 at 10 Ahmedabad (see Table 1). However, the maximum ozone levels are similar for both the years.

Highest ozone levels were observed again at Khambat in the afternoon hours ranging from 70 to $110 \mathrm{ppbv}$ through out the observational period during the second campaign. The mean of the peak ozone for all the observational data during afternoon 15 hours is $88 \mathrm{ppbv}$. The average ozone increase rate from sunrise to afternoon hours is about $10 \mathrm{ppbv} \mathrm{h}^{-1}$ leading to high ozone buildup with an amplitude of about $58 \mathrm{ppbv}$. There is very less day-to-day ozone variability during 08:00-12:00 $\mathrm{h}$ and 17:00-19:00 $\mathrm{h}$ comparing the variability at night and afternoon hours. The observed ozone levels at Khambat are about $63 \%$ higher than the urban site Ahmedabad. The ozone variations and its amplitude are consistent with the observations made during the first campaign in January 2001.

Figure 3d shows diurnal variation of ozone observed on 25 January along the northern coast of the Arabian Sea from Mahua to Khambat across the Bhavnagar city (see Fig. 1 for the mobile track). The ozone levels dropped from 63 ppbv to about $37 \mathrm{ppbv}$ 25 and came back almost to its original level when the observations were taken across the city of Bhavanagar. The difference in the ozone values outside and inside the city was around $26 \mathrm{ppbv}$. The difference in ozone inside and outside of the Bhavnagar city is similar with the ozone difference from urban center (Ahmedabad) to its downwind regions observed during both the mobile campaigns (Figs. 3a-3c). This indicates that

4, 3359-3380, 2004

High ozone at rural sites in India

D. Chand and S. Lal

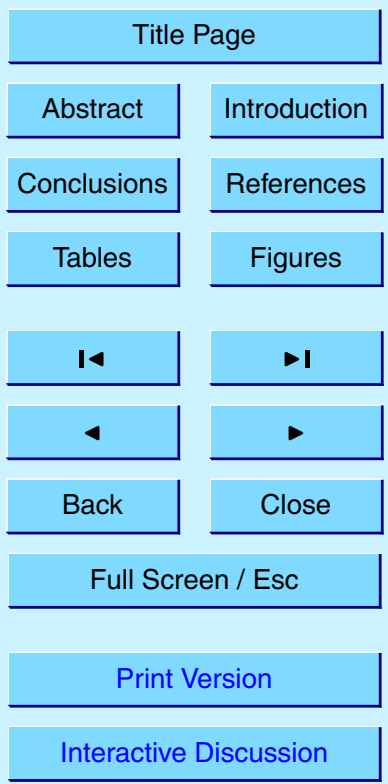

(C) EGU 2004 
the net production efficiency of $\mathrm{O}_{3}$ in urban environments is significantly lower than its downwind out flow regions.

Figure 4 shows the correlations of $\mathrm{O}_{3}$ at urban site (Ahmedabad) and its downwind rural location at Khambat in shape of hysteresis loop as shown by curves 1,2 and

53 . The buildup of ozone in morning to afternoon hours in downwind site is more pronounced than at urban site Ahmedabad. The magnitude of increase rate in $\mathrm{O}_{3}$ from morning to afternoon hours is higher than the decrease rate from afternoon to evening hours at both sites. The higher increase rate in morning hours is as a result of $\mathrm{O}_{3}$ production by in-situ photochemistry and by mixing the ozone rich air from the free 10 troposphere to the boundary layer. Summary of the increase rates of ozone is given in Table 1.

\subsection{Ozone at other stations in India}

The ozone levels at Ahmedabad and its downwind sites are compared with observations from free tropospheric site at Mt. Abu and a rural site at Gadanki in winter of 2001.

15 Figure 5 shows a comparison of the diurnal variations of ozone observed at Mt. Abu, Gadanki, Ahmedabad and downwind of urban environment at Khambat. The observed ozone levels at Mt. Abu in night hours are higher than daytime. Also, there is a net ozone loss (4 ppbv) at Mt. Abu during the daytime without any significant change in ozone levels during the night hours. The decrease in $\mathrm{O}_{3}$ concentration in day time at 20 Mt. Abu is attributed to mixing of ozone poor air from boundary layer to the free troposphere. Carbon monoxide (CO) is used as a tracer for this mixing. Figure 6 shows the average diurnal variation of $\mathrm{CO}$ at $\mathrm{Mt}$. Abu in winter. The observed nitric oxide (NO) levels at Mt. Abu are too low to lead a significant $\mathrm{O}_{3}$ production (Naja et al., 2003; Chand, 2002). The average ozone during night time in the month of January is about $2542 \pm 6$ ppbv and there is no significant difference in ozone levels in this season during 2000 and 2001. Gadanki is a rural environment in south India exhibiting diurnal variation similar to the rural sites upwind of Ahmedabad with noontime maximum of $45 \mathrm{ppbv}$ and a minimum of 8 ppbv before sunrise. All these unpolluted rural sites do not show

ACPD

4, 3359-3380, 2004

High ozone at rural sites in India

D. Chand and S. Lal

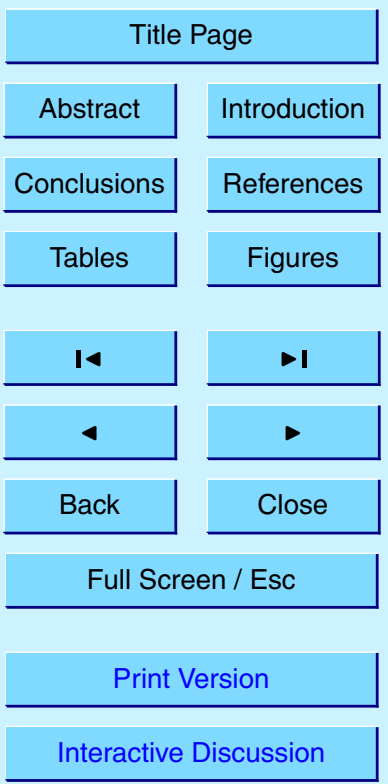

(C) EGU 2004 


\section{Discussion}

4, 3359-3380, 2004

The stable levels of ozone at Mt. Abu $\left[\mathrm{d}\left(\mathrm{O}_{3}\right) / \mathrm{dt} \approx 0\right]$ in night can be used to show that this site has a signature of free troposphere in the month of January. This is further supported by low levels of $\mathrm{CO}$ in night and its high levels in day time (see Fig. 6). The $\mathrm{O}_{3}$ poor and $\mathrm{CO}$ rich air from boundary layer mixes with the air in the free troposphere and leads to increase in $\mathrm{CO}$ and decrease in $\mathrm{O}_{3}$ concentrations after sunrise. Using $\mathrm{O}_{3}$ and $\mathrm{CO}$ variations as a tracer of air mass, ozone levels in night hours (18:00-06:00 h) at this site can be taken as background level for this region. The mean night time ozone at this site is $42 \pm 6$ ppbv in the month of January 2000 and 2001 . There is no significant difference in average ozone levels in January of 2000 and 2001. This indicates that this site is free from the small scale (local) perturbations.

The observed ozone levels at Ahmedabad during the first and second campaigns of MOLEX in January 2001 and 2002, as shown in the Figs. 3a and 3c, are consistent and 15 repeating in magnitude. Also, these ozone observations at Ahmedabad are in general conformity of earlier measurement by Lal et al. (2000) at this site.

Ozone levels observed at Mt. Abu, Gadanki and the coastal environment at Thumba (Nair et al., 2002) have rarely crossed $60 \mathrm{ppbv}$ in the month of January. Back trajectory analyses at Mt. Abu in January 2000 and 2001 (not shown here) indicate that the 20 air descended from the free troposphere almost all the times without showing any significant high levels of ozone. Khambat, in the downwind of Ahmedabad, is also an entry point of pollutants to the Arabian Sea (see Fig. 1). Forward trajectory analysis shows that the polluted plumes from this region can get transported more than $3000 \mathrm{~km}$ to the marine boundary layer over the Arabian Sea and the Indian Ocean within a week. Comparing this site with the other rural sites and free tropospheric site, it is most likely that high levels of ozone at Khambat are results of photochemical production from the urban pollutants. The excess ozone concentration in the plums downwind of urban site

High ozone at rural sites in India

D. Chand and S. Lal

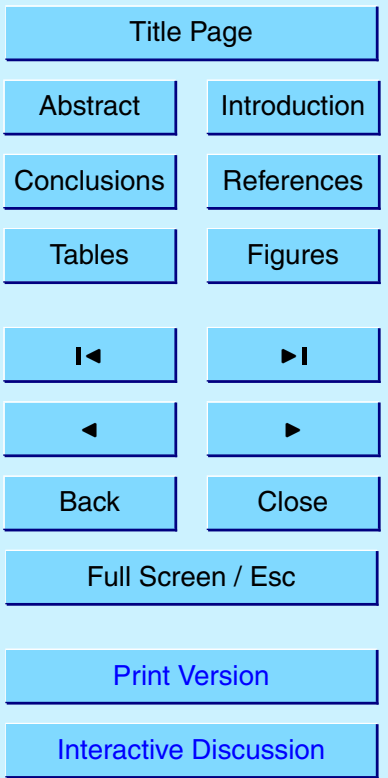

(C) EGU 2004 
$\left(\mathrm{O}_{3}\right.$ in downwind - Background $\left.\mathrm{O}_{3}\right)$ is $46 \mathrm{ppbv}$. The ozone level in downwind of urban environment is more than a factor of 2 higher than the background ozone in this region.

\section{Summary and conclusions}

Surface ozone $\left(\mathrm{O}_{3}\right)$ levels are observed in rural, urban and free troposphere environ5 ments in winter (January) of 2001 and 2002 as a part of a Mobile Lab Experiment (MOLEX) in western India. Elevated $\mathrm{O}_{3}$ up to $110 \mathrm{ppbv}$ were recorded in afternoon hours at rural sites in downwind of major industrial region of Gujarat (India) adjoining the Arabian Sea during these campaigns. These are the first $\mathrm{O}_{3}$ observations at urban center and its upwind and downwind sites over the Indian subcontinent.

10 The observations at urban centers (Ahmedabad and Bhavnagar city) show low levels of ozone $(<60 \mathrm{ppbv})$. The ozone levels at rural site are found to be about $60 \%$ higher than its upwind urban center at Ahmedabad (Table 1). The repeated observations in January 2001 as well as 2002 indicate that the elevated ozone in the downwind of urban centers of Gujarat is a regular process in this season. Khambat, being an entry 15 point to the Arabian Sea, is feeding high levels of ozone over this marine environment. Seven days forward trajectories show polluted air transporting more than $3000 \mathrm{~km}$ in the boundary layer from Ahmedabad over the Arabian Sea and the Indian Ocean reaching up to inter-tropical convergence zone (ITCZ) near $5^{\circ} \mathrm{S}$. It is highly possible that the elevated ozone observed during INDOEX 1999 over the Arabian Sea downwind of western India was the result of outflow of pollutants transported from the urban centers. Observations at Mt. Abu, Ahmedabad and its downwind sites suggest that the elevated ozone in downwind of urban centers is a result of photochemical production by outflow of urban pollutants. The background ozone in free troposphere at a height of $1680 \mathrm{~m}$ in this regions is $42 \pm 6$ ppbv in month of January. The observed ozone level in downwind of urban center is a factor of 2 higher than the background ozone concentration. The net excess ozone in the plumes downwind of urban center is about $46 \mathrm{ppbv}$.

Though the transport of pollutants from the urban region over long distances is an
ACPD

4, 3359-3380, 2004

High ozone at rural sites in India

D. Chand and S. Lal

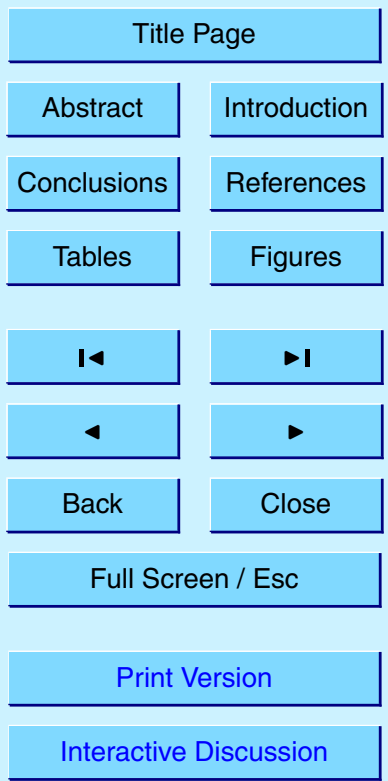

(C) EGU 2004 
observed fact in the North America and Europe, these observations suggest that elevated ozone downwind of urban centers in India can significantly affect the composition of air on the way at land as well as over the marine environments in the winter season. Similar to the horizontal transport in downwind of urban centers, ozone and its precur5 sors can lead high $\mathrm{O}_{3}$ in the free troposphere under convection and turbulent activities during the summer. Ozone has longer lifetime over the marine environment and the free troposphere and it may get transported to regional or even at global scales. Apart from the climatic implications, the landlocked polluted urban centers like Delhi, etc may have significant health and crop implications in the rural areas in their downwind sites 10 in the Indian subcontinent.

Since these are the first limited observations in downwind of urban environment in India, it is difficult to assess the magnitude of the ozone production by other major urban centers in their downwind areas. In order to better understand the budget of the tropospheric ozone and its impact on human health and vegetation, the study of transport of pollutants in India has to be supported by extensive measurements at the urban centers as well as their downwind regions. Systematic observations of ozone and its precursors at elevated site (e.g. at Mt. Abu) along with measurements in rural, urban and marine environments over Indian subcontinent can be valuable for assessment of tropospheric ozone budget in this region.

20 Acknowledgements. We are thankful to Messers S. Venkataramani, K. S. Modh, T. K. Sunil, and S. Desai for the active support in experiments. The corresponding author, D. Chand acknowledges M. O. Andreae, P. Crutzen and M. G. Lawrence for helpful discussions. We thank National Oceanic and Atmospheric Administration (NOAA) for providing free access for downloading the forward trajectories and wind fields from the site http://www.arl.noaa.gov/ready/
ACPD

4, 3359-3380, 2004

High ozone at rural sites in India

D. Chand and S. Lal

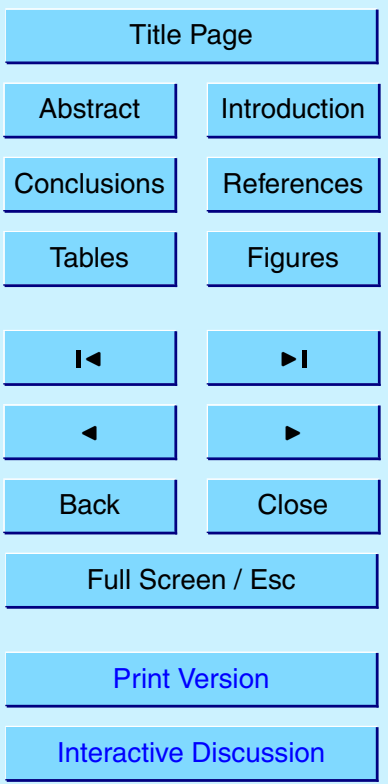

(C) EGU 2004 


\section{References}

Asnani, G. C.: Climatology of the tropics, in Tropical Meteorology, Indian Institute of Tropical Meteorology, Pune, India, I, 100-204, 1993.

Ballaman, R.: Transport of ozone in Switzerland, Science of the Total Environment, 134, 103115, 1993.

Brasseur, G. P., Orlando, J. J., and Tyndall, G. S. (Eds.): Atmospheric Chemistry and Global Change, 13, 465-486, Oxford Univ. Press, New York, 1999.

Crutzen, P. J., Lawrence, M. G., and Pöschl, U.: On the background photochemistry of tropospheric ozone, Tellus, 51 A-B, 123-146, 1999.

Chameides, W. L., Kasibhata, P. S., Yienger, J., and Levy II, H.: Growth of continental-scale metro-plexes, regional pollution and world food production, Science, 264, 74-77, 1994.

Chameides, W. L., Xingsheng, L., Xiaoyan, T., Xiuji, Z., Chao, L., Kiang, C. S., St. John, J., Saylor, R. D., Liu, S. C., Lam, K. S., Wang, T., and Giorgi, F.: Is Ozone Pollution Affecting Crop Yields in China?, Geophys. Res. Lett., 26, 867-870, 1999.

15 Chand, D.: Study of trace gases in the tropical troposphere, Ph.D. Thesis, MLS University, Udaipur, India, July, 2002.

Chand, D., Lal, S., and Naja, M.: Variations of ozone in the marine boundary layer over the Arabian Sea and the Indian Ocean during the 1998 and 1999 INDOEX campaigns, J. Geophys. Res., 108, D6, 4190, doi:10.1029/2001JD001589, 2003.

Chang, L., Miller, F. J., Ultman, J., Huang, Y., Stockstill, B. L., Grose, E., Graham, J. A., Ospital, J. J., and Crapo, J. D.: Alveolar epithetlial cell injuries by subchronic exposure to low concentrations of ozone correlate with cumulative exposure, Toxicology and Applied Pharmacology, 109, 219-234, 1991.

Draxler, R. R. and Hess, G. D.: An overview of the HySPLIT-4 modeling system for trajectory, dispersion and deposition, Aust. Met. Mag., 47, 295-308, 1998.

Hogsett, W. E., Weber, J. E., Tingey, D. T., Herstrom, A. A., Lee, E. H., and Laurence, J. A.: An approach for characterizing tropospheric ozone risk to forests, Environmental Management, 21, 105-120, 1997.

Jonson, J. E., Sundet, J. K., and Tarrason, L.: Model calculations of present and future levels of ozone and ozone precursors with a global and a regional model, Atmos. Env., 35, 525-537, 2001.

Kelly, N. A., Wolff, G. T., and Ferman, M. A.: Sources and sinks of ozone in rural areas, Atmos.
ACPD

4, 3359-3380, 2004

High ozone at rural sites in India

D. Chand and S. Lal

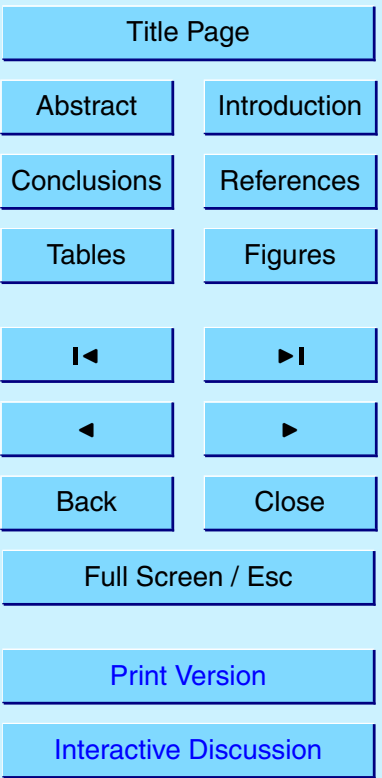

(c) EGU 2004 
Env., 18, 1251-1266, 1984.

Khemani, L. T., Momin, G. A., Rao, P. S. P., Vijayakumar, R., and Safai, P. D.: Study of surface ozone behavior at urban and forested sites in India, Atmos. Environ., 29, 2021-2024, 1995.

Kley, D., Kleinmann, M., Sanderman, H., and Krupa, S.: Photochemical oxidants: state of the $5 \quad$ science, Environmental Pollution, 100, 19-42, 1999.

Krupa, S. V., Grünhage, L., Jäger, H.-J., Nosel, M., Manning, W. J., Legge, A. H., and Hanewald, K.: Ambient ozone $\left(\mathrm{O}_{3}\right)$ and adverse crop response: a unified view of cause and effect, Environmental Pollution, 87, 119-126, 1995.

Lal, S., Naja, M., and Subbaraya, B. H.: Seasonal variations in surface ozone and its precursors over an urban site in India, Atmos. Environ., 34, 2713-2724, 2000.

Lal, S. and Lawrence, M. G.: Elevated mixing ratios of surface ozone over the Arabian Sea, Geophys. Res. Lett., 28, 1487-1490, 2001.

Lelieveld, J., Crutzen, P. J., Ramanathan, V., et al.: The Indian Ocean Experiment: Widespread Air Pollution from South and Southeast Asia, Science, 291, 1031-1036, 2001.

Miller, F. J.: Uptake and fate of ozone in the respiratory tract, Toxicology Letters 82, 277-285, 1995.

Nair, P. R., Chand, D., Lal, S., Modh, K. S., Naja, M., Parameswaran, K., Ravindran, S., and Venkataramani, S.: Temporal variations in surface ozone at Thumba $\left(8.6^{\circ} \mathrm{N}, 77^{\circ} \mathrm{E}\right)-$ a tropical coastal site in India, Atmos. Environ., 36, 603-610, 2002.

20 Naja, M. and Lal, S.: Changes in surface ozone amount and its diurnal and seasonal patterns, from 1954-1955 to 1991-1993, measured at Ahmedabad (23N N), India, Geophys. Res. Lett., 23, 81-84, 1996.

Naja. M. and Lal, S.: Surface ozone and precursor gases at Gadanki (13.5 N, $\left.79.2^{\circ} \mathrm{E}\right)$, a tropical rural site in India, J. Geophys. Res., 107, D14, 4197, doi:10.1029/2001JD000357, 252002.

Naja, M., Lal, S., and Chand, D.: Diurnal and seasonal variabilities in the surface ozone at a high altitude station Mt. Abu (24.6 N, 72.7 $\left.{ }^{\circ} \mathrm{E}, 1680 \mathrm{~m}\right)$ in India, Atmos. Env., 37, 4205-4215, 2003.

Proyou, A. G., Toupance, G., and Perros, P. E.: A two year study of ozone behaviours at rural and forested sites in eastern France, Atmos. Env., 25, 2145-2153, 1991.

Ramanathan, V., Crutzen, P. J., Kiehl, J. T., and Rosenfeld, D.: Aerosols, climate and the hydrological cycle, Science, 294, 2119-2124, 2001.

Reich, P. B. and Amundson, R. G.: Ambient levels of ozone reduce net photosynthesis in tree

\section{ACPD}

4, 3359-3380, 2004

High ozone at rural sites in India

D. Chand and S. Lal

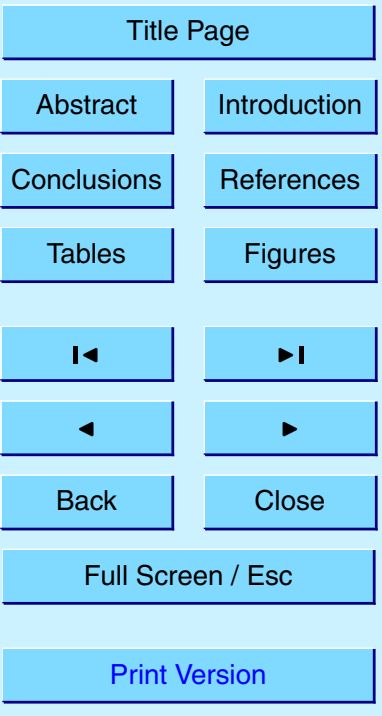

Interactive Discussion

(C) EGU 2004 
and crop species, Science, 230, 566-570, 1985.

Varshney, C. R. and Aggarawal, M.: Ozone pollution in the urban atmosphere of Delhi, Atmos.

Environ., 26, 291-294, 1992.

\section{ACPD}

4, 3359-3380, 2004

High ozone at rural

sites in India

D. Chand and S. Lal

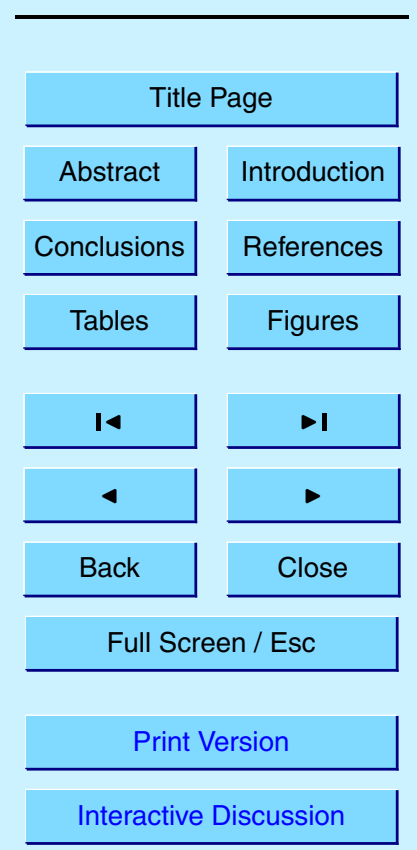

(C) EGU 2004 


\section{ACPD}

4, 3359-3380, 2004

Table 1. Average ozone parameters at Ahmedabad (urban) and Khambat (rural) during MOLEX. The minimum ozone is observed before sunrise and maximum in the afternoon hours.

\begin{tabular}{|c|c|c|c|}
\hline Campaign period & $\begin{array}{l}\text { Average observed } \\
\text { Parameter }\end{array}$ & $\begin{array}{l}\text { Observations at } \\
\text { Ahmedabad } \\
\text { (Urban site) }\end{array}$ & $\begin{array}{l}\text { Observations at } \\
\text { Khambat } \\
\text { (Downwind site) }\end{array}$ \\
\hline 22-27 January 2001 & $\begin{array}{l}\text { Afternoon } \mathrm{Max}_{3} \mathrm{O}_{3} \\
\text { Morning Min } \mathrm{O}_{3} \\
\text { Amplitude of } \mathrm{O}_{3}\end{array}$ & $\begin{array}{l}52 \pm 4 \text { ppbv } \\
12 \pm 3 \text { ppbv } \\
40 \text { ppbv }\end{array}$ & $\begin{array}{l}80 \mathrm{ppbv} \\
25 \mathrm{ppbv} \\
65 \mathrm{ppbv}\end{array}$ \\
\hline & $\begin{array}{l}\mathrm{O}_{3} \text { increase rate } \\
\text { (hourly } \mathrm{dO}_{3} / \mathrm{dt} \text { ) }\end{array}$ & $6.7 \mathrm{ppbv} \mathrm{h}^{-1}$ & $10.0 \mathrm{ppbv} \mathrm{h}^{-1}$ \\
\hline $\begin{array}{l}30 \text { December } 2001 \text { - } \\
5 \text { January } 2002\end{array}$ & $\begin{array}{l}\text { Afternoon } \mathrm{Max}_{3} \mathrm{O}_{3} \\
\text { Morning Min } \mathrm{O}_{3} \\
\text { Amplitude of } \mathrm{O}_{3} \\
\mathrm{O}_{3} \text { increase rate } \\
\text { (hourly } \mathrm{dO}_{3} / \mathrm{dt} \text { ) }\end{array}$ & $\begin{array}{l}55 \pm 6 \mathrm{ppbv} \\
28 \pm 4 \mathrm{ppbv} \\
27 \mathrm{ppbv} \\
4.2 \mathrm{ppbv} \mathrm{h}^{-1}\end{array}$ & $\begin{array}{l}88 \pm 13 \text { ppbv } \\
24 \pm 3 \text { ppbv } \\
63 \text { ppbv } \\
9.9 \mathrm{ppbv} \mathrm{h}^{-1}\end{array}$ \\
\hline
\end{tabular}

High ozone at rural sites in India

D. Chand and S. Lal

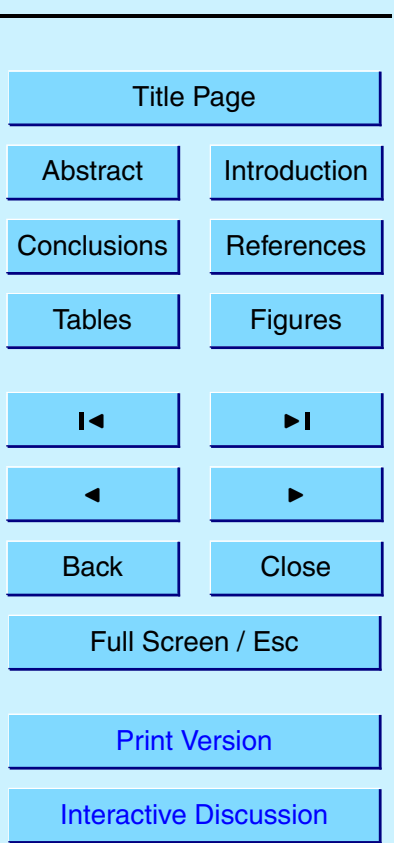

(c) EGU 2004 


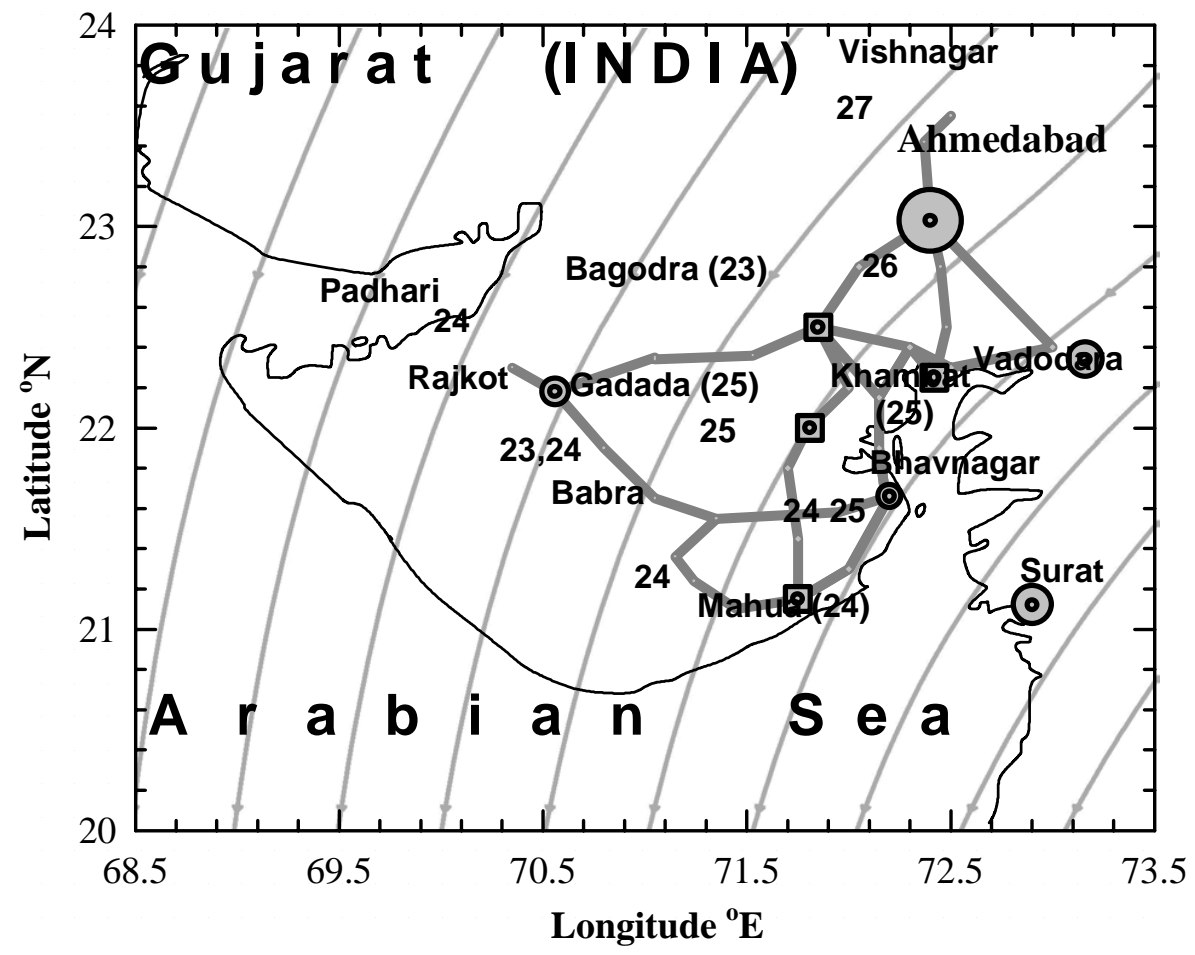

Fig. 1. Geographical location of the tracks covered by the mobile vans in January 2001. Circle represents the urban centers, size of the circle is proportional to the population of the urban center. Numbers on track indicate the date of the observations. Observations taken at stationary phase are the sites represented by the square symbols on the dates embedded in the brackets. Faint thin curved lines are the average NCEP wind flow at $925 \mathrm{mb}$ during the observational period.

\section{ACPD}

4, 3359-3380, 2004

High ozone at rural sites in India

D. Chand and S. Lal

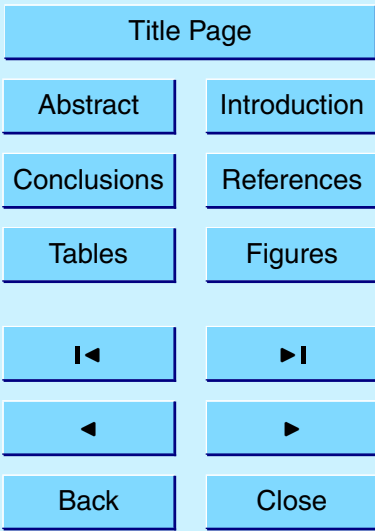

Full Screen / Esc

Print Version

Interactive Discussion

(C) EGU 2004 


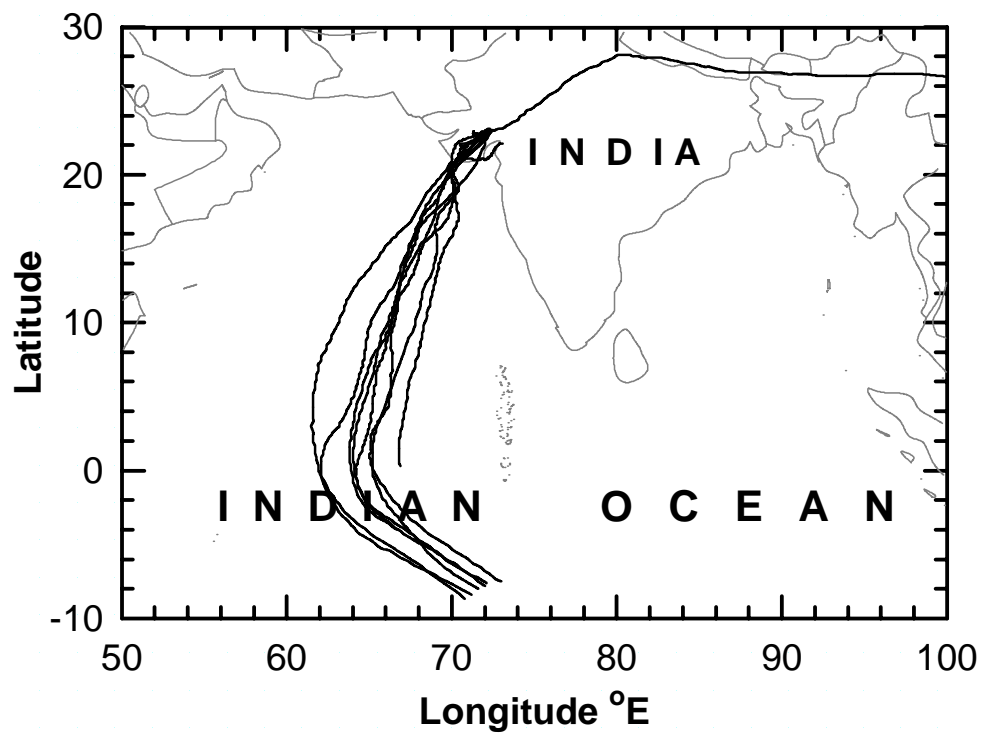

ACPD

4, 3359-3380, 2004

High ozone at rural sites in India

D. Chand and S. Lal

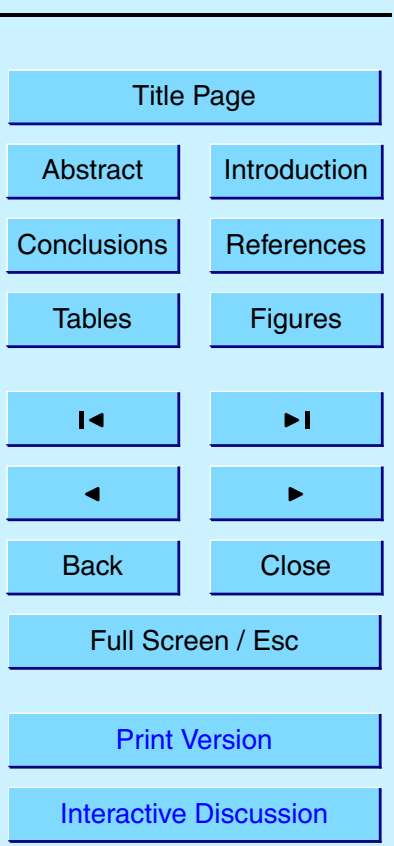

Fig. 2. Seven days, three dimensional forward trajectories showing the air parcel flow starting from the urban center Ahmedabad at an altitude of $500 \mathrm{~m}$ to its downwind rural areas and farther over the Arabian Sea and the Indian Ocean during 23-27 January 2000.

(C) EGU 2004 

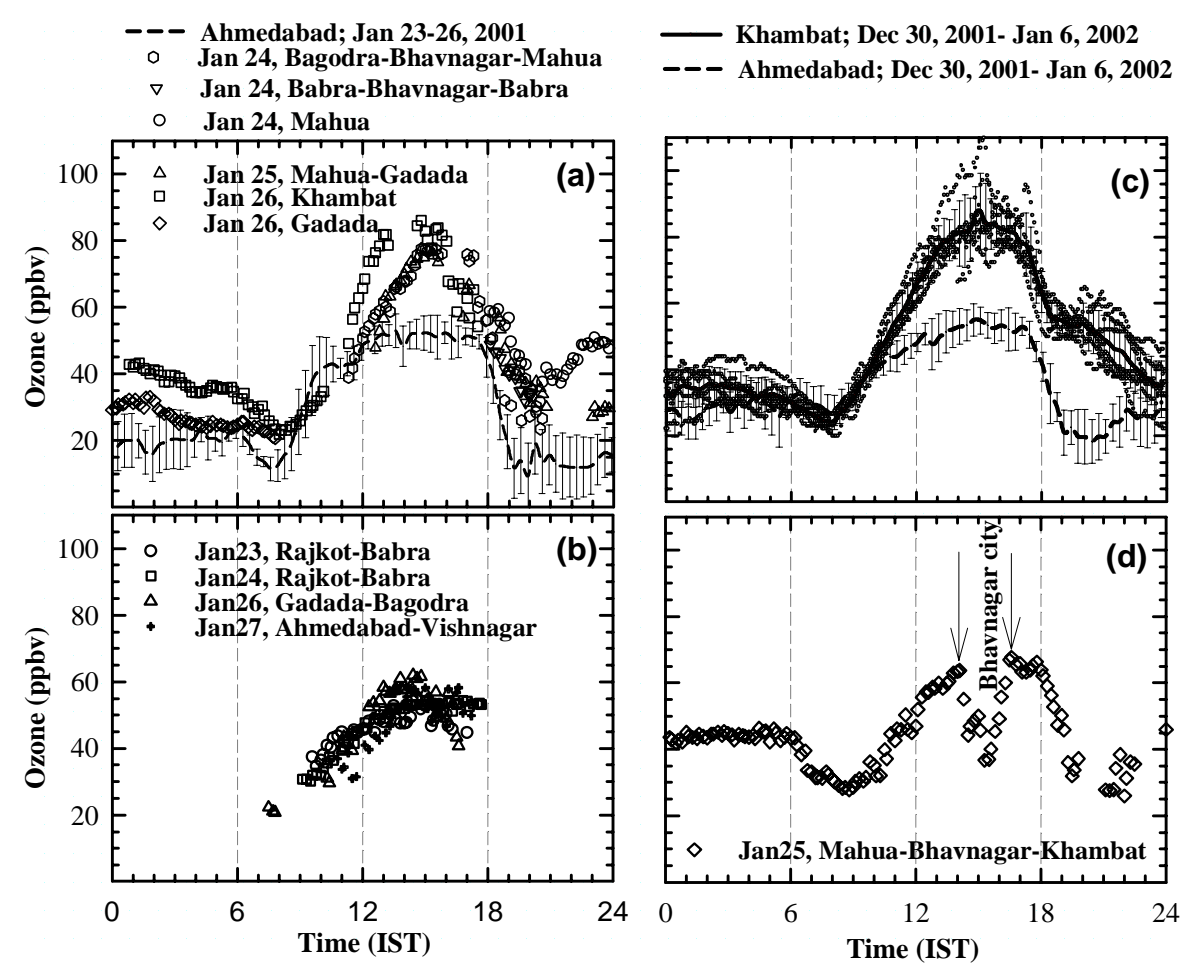

ACPD

4, 3359-3380, 2004
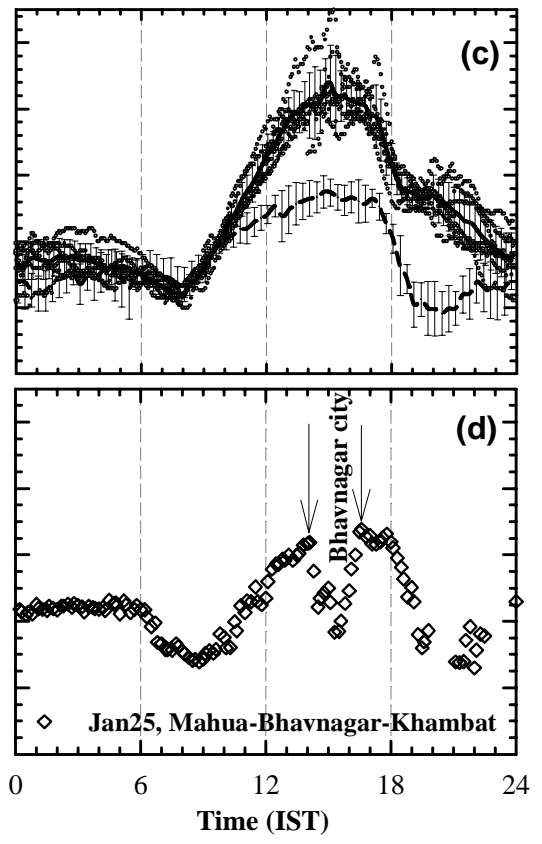

High ozone at rural
sites in India

D. Chand and S. Lal

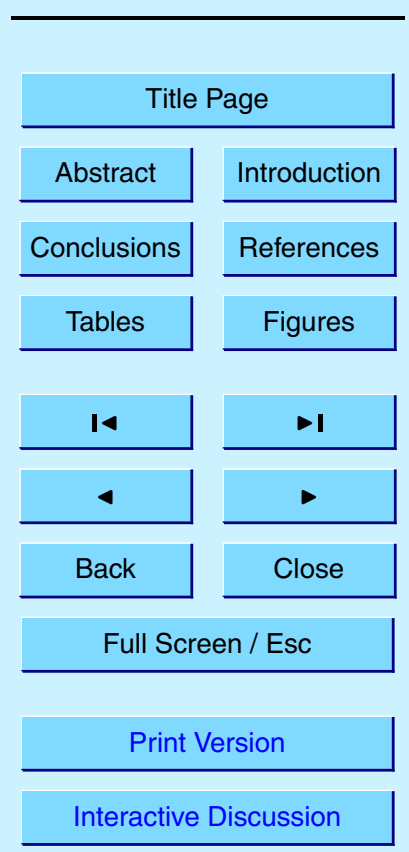

Fig. 3. Diurnal variations in ozone at urban center (Ahmedabad) and its surrounding sites during both the campaigns in 2001 and 2002; (a) diurnal variations of ozone at Ahmedabad and its downwind sites; (b) diurnal variations in west and upwind direction of Ahmedabad; (c) diurnal variations of ozone at Ahmedabad and its downwind (Khambat) from 30 December 2001 to 6 January 2002. Dots represent the measurements at $1 \mathrm{~min}$ time interval during the campaign period ( 7 days). Dashed and continuous curve lines are the average diurnal variation of all the data for both sites; (d) diurnal variations of ozone on Mahua-Bhavnagar-Khambat mobile track on 25 January 2001. The dip labeled between arrow marks is ozone levels measured in afternoon hours at the time when Bhavnagar city was crossed (as mentioned in d). 


\section{ACPD}

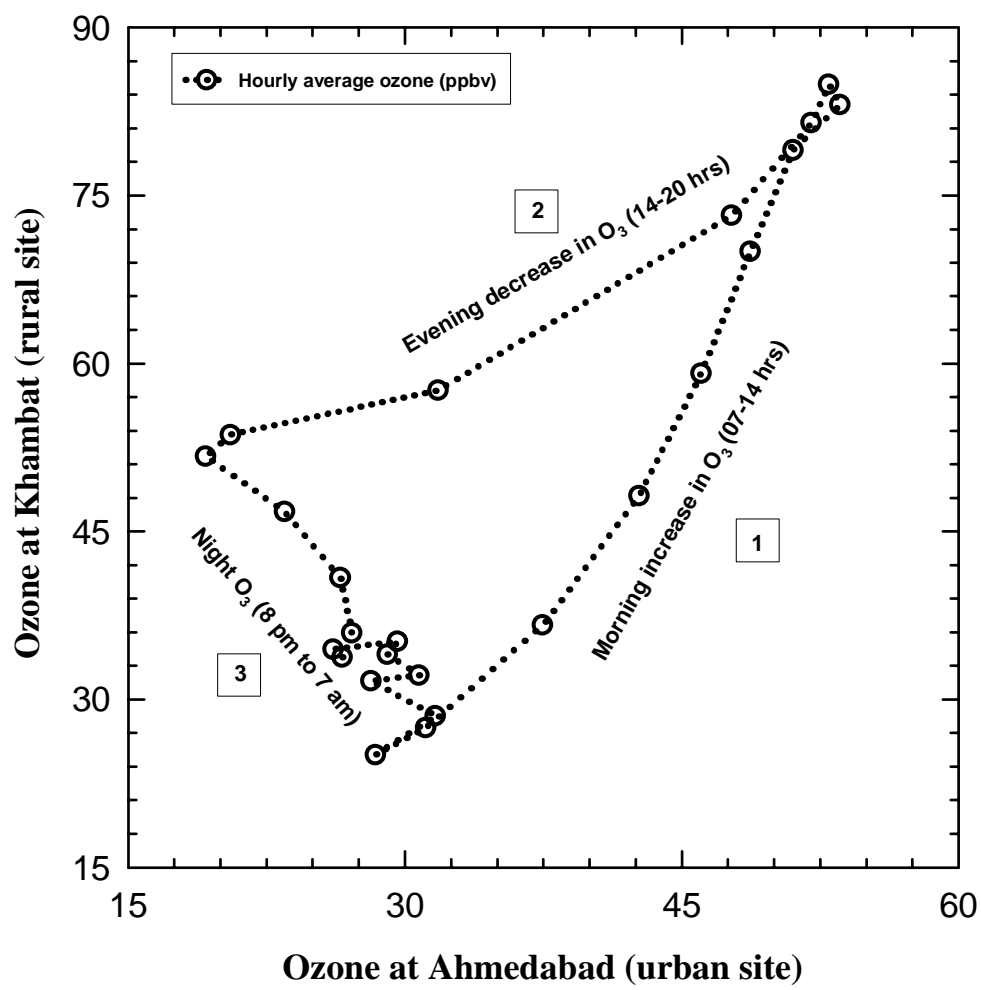

4, 3359-3380, 2004

High ozone at rural sites in India

D. Chand and S. Lal

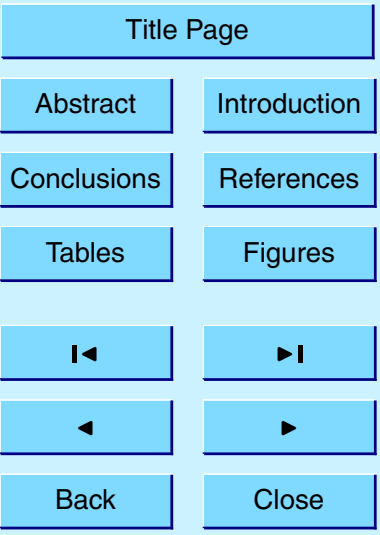

Full Screen / Esc

Print Version

Fig. 4. Correlations in $\mathrm{O}_{3}$ at urban (Ahmedabad) and its downwind rural (Khambat) sites. The open circles are hourly average made from 7 days data. Curve 1, 2 and 3 show the increase in $\mathrm{O}_{3}$ from morning to afternoon hours, decrease in $\mathrm{O}_{3}$ from afternoon to evening hours and decrease/increase in $\mathrm{O}_{3}$ during nighttime, respectively at both the sites.

nteractive Discussion

(c) EGU 2004 


\section{ACPD}

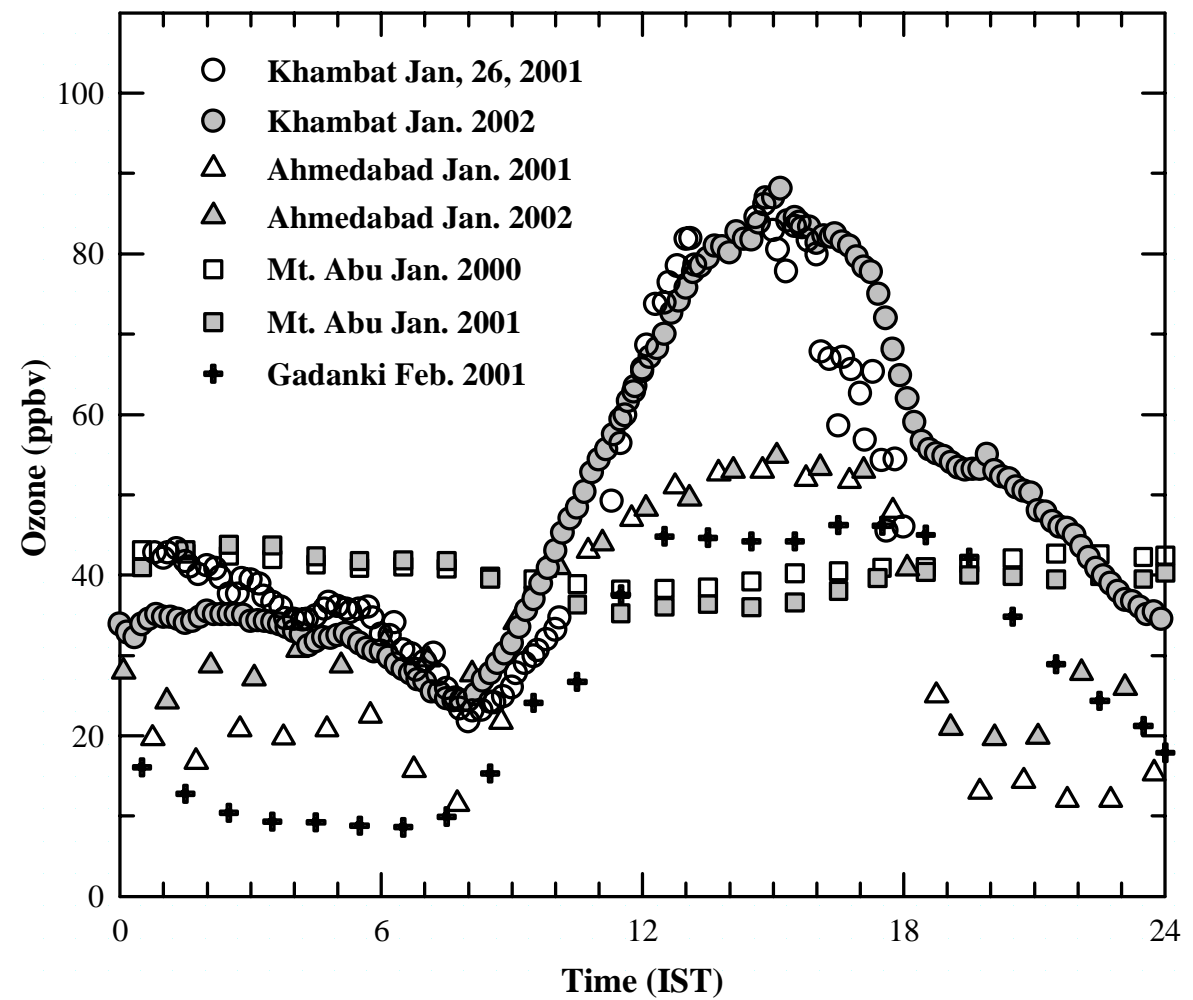

Fig. 5. Comparison of the elevated ozone at rural site in downwind of the urban environment (circles) along with the observations taken at other different sites in urban (triangles), rural (crosses) and free tropospheric environments (squares) in India. The data at Mt. Abu and Gadanki represent monthly averages.
4, 3359-3380, 2004

High ozone at rural sites in India

D. Chand and S. Lal

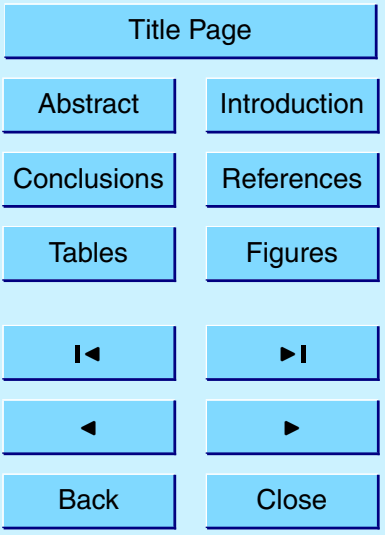

Full Screen / Esc

Print Version

Interactive Discussion

(c) EGU 2004 


\section{ACPD}

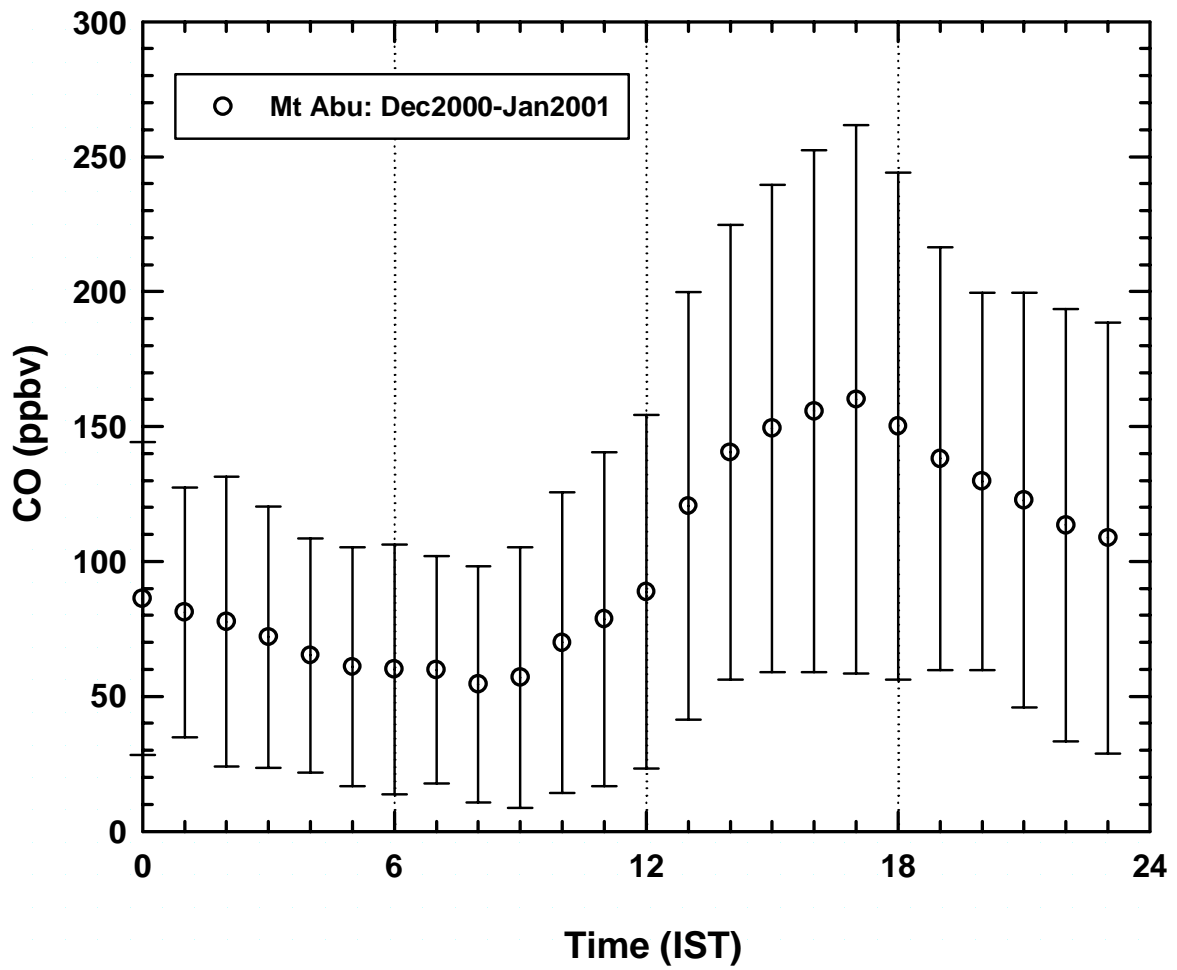

4, 3359-3380, 2004

High ozone at rural sites in India

D. Chand and S. Lal

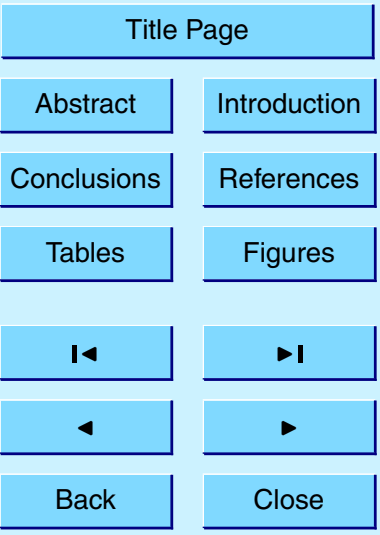

Full Screen / Esc

Print Version

Fig. 6. Diurnal variation in average concentration of CO at Mt. Abu for December 2000 and January 2001. The vertical bars show variability of $1 \sigma$ in $\mathrm{CO}$ concentrations for both the months.

Interactive Discussion

(C) EGU 2004 